\title{
Determination of Purchase Intention Applying Technology Acceptance Model: A Case of Facebook Influence
}

\author{
Udgam Mishra \\ Lecturer \\ Faculty of Management, M. M. A. M. Campus, Biratnagar, Tribhuvan University, Nepal \\ Email: shreeudh@gmail.com \\ DOI: https://doi.org/10.3126/dristikon.v10i1.34575
}

\begin{abstract}
The paper aims to determine the influence of Facebook on purchase intention applying Technological acceptance model. The data are obtained from self-administered questionnaire of Facebook users of Biratnagar. The response received has been analyzed by several statistical tools namely Frequency Distribution, Cronbach's Alpha Reliability test, Pearson Correlation Coefficient and Linear Regression Analysis, computed by Software Package for Social Science (SPSS) version 26. The main conclusion drawn from this study states that perceived usefulness and perceived ease to use have significant relationship with purchase intention. The findings reveal that perceived usefulness has more influence on purchase intention than ease to use. This study recommends that Marketers should give more focus on branding the Facebook page and maintain immediate connection with Facebook users.
\end{abstract}

Keywords: Perceived usefulness, perceived ease to use, purchase intention, Facebook

\section{Introduction}

\section{Background}

The past couple decades have noticed remarkable growth in technological innovation regard to social media platforms. Razorfish (2009), the use of social media to influence others is giving rise to completely new types of marketing; in this case, "Social Influence Marketing." Times have changed when social media was used just for sharing information and news. Social media as changed the way companies communicate with consumers. Not only has social media created new marketing opportunities for companies (Bruhn, Schoenmueller, \& Schafer, 2012) but also companies can use social media to engage in a dialog with consumers and to promote their brand and market their products/services (Lin, Li, \& Wang, 2017). Social media is an information bank about products and services. Social media has become an opportunity for consumers to share views and opinions about products and services (Lin, Li, \& Wang, 2017). and to create content about brands and products (Wang, 2017). Consumers with this facility share their views and opinions time and often. Kahraman (2010) defines Facebook as "the online platform that people use to share their ideas, experience, and perspectives and communicate with each other" 
The behavior of consumers has changed especially giving more importance to online shopping. This process related to meeting the needs of consumers defined as an electronic process and it stated that social media plays an important role in this regard (Isra et al., 2015). Growing popularity of Facebook has induced many businesses to place their ads on Facebook for creation of awareness and influencing buyer behavior. Vahl (2011) suggests business attraction towards Facebook and states that approx $\$ 2.5$ billion is revenue generated from Facebook. In present intense competition Facebook Ads are playing crucial part to deliver the intended message to target audience. Kountouridou, M., \& Ioannou, P. (2019) suggest that a promotional message on a brand page on Facebook increases consumer interaction and brand engagement, forming positive attitudes which lead to users' intention to purchase as a result.

\section{Research Problem}

There are more than 9.8 million Facebook users in Nepal which accounts to $32.3 \%$ of entire population (NapoleonCat, 2019) and their daily usage is approx. 1-2 hours a day. This gives a rise on the study of impact of Facebook on purchase intention of consumers. Based on our review of existing scientific literature on social media, few empirical studies have been conducted to scientifically evaluate and explain the usage behavior of social media using Facebook (Rauniar, R.., Rawski., G., Jei, Y., \& Johnson, B. (2014)

This paper will take a deep look on how Facebook engagement and usage influence the purchase intention of users. Following are the research problems:

- Does Facebook have effect on intention to purchase applying TAM?

- What is the effect of perceived usefulness and ease to use on intention to purchase?

\section{Research Objectives}

The main objective of this paper is to determine the influence level of Facebook on intention to purchase:

- To examine the effect of Facebook on intention to purchase.

- To measure the effect of Perceived usefulness and ease of use on behavior intention.

\section{Hypothesis}

Research hypothesis are the assumptions about the research. Hypothesis will be tested using different statistical tools. Following are the formulated hypothesis:

$\mathrm{H}_{1}$ : There is no significant relationship between perceived usefulness and intention to purchase.

$\mathrm{H}_{2}$ : There is no significant relationship between perceived ease of use and intention to purchase. 


\section{Research Significance}

The study will have the following significance in the future:

- This study will work as base for marketers while making marketing policies.

- This study will suggest the Facebook influence on purchase intention.

- This study will work as a foundation for future work.

\section{Literature Review}

Promotional message on a brand page on Facebook increases consumer interaction and brand engagement, forming positive attitudes which lead to users' intention to purchase as a result (Kountouridou, Ma \& Ioannou, P. 2019). MacMillan (2009) advocates that with continuation of time and slow introduction of online purchase, social networking sites like Facebook will become popular platform for online purchase. He even adds that new shopping can be adopted because of Facebook. The results of the study showed that Facebook advertising significantly affected brand image and brand equity, both of which factors contributed to a significant change in purchasing intention (Dehghani, M., \& Tumer, M. (2015). Attitude towards FB advertising is one of the major factors affecting the purchasing decision. Consumers with a positive attitude about a product are expected to take actions that show their positive attitude, and thus are expected to: behave positively to social media advertising; purchase brands promoted on social media, or search for extra data (Wang, \& Sun, 2010).

Moreover, Kang, K. Y., \& Jin, H. J. (2007), found that perceived usefulness and perceived ease to use affected attitude to use and attitude to use affected intention to purchase. A study conducted in Malaysia by Bakar, A., \& Syuhaidi, M. (2013) among youth aged between 15-29 years regarding movie mobile advertising reveals significant relationship between technological model: ease to use and usefulness and movie purchase intention.

\section{Technological Accepted Model}

Davis, F. D., Bagozzi, R., \& Warshaw, P. (1989) stated that TAM, TPB and TRB models are not useful to foresee, but describe in way researcher and professional identify the key reasons for accepting system or technology and find ways to implement corrective adequate steps. Technology influences people in many ways. Not all the technology is accepted by every people. In 1989, Fred Davis developed a model which describes that there are two presumes a mediating role of two variables called perceived ease of use and perceived usefulness in a complex relationship between system characteristics (external variables) and potential system usage". (Marangrunic, N., \& Granic, A. 2013). 


\section{Figure 1}

Technology Acceptance Model Version 1.

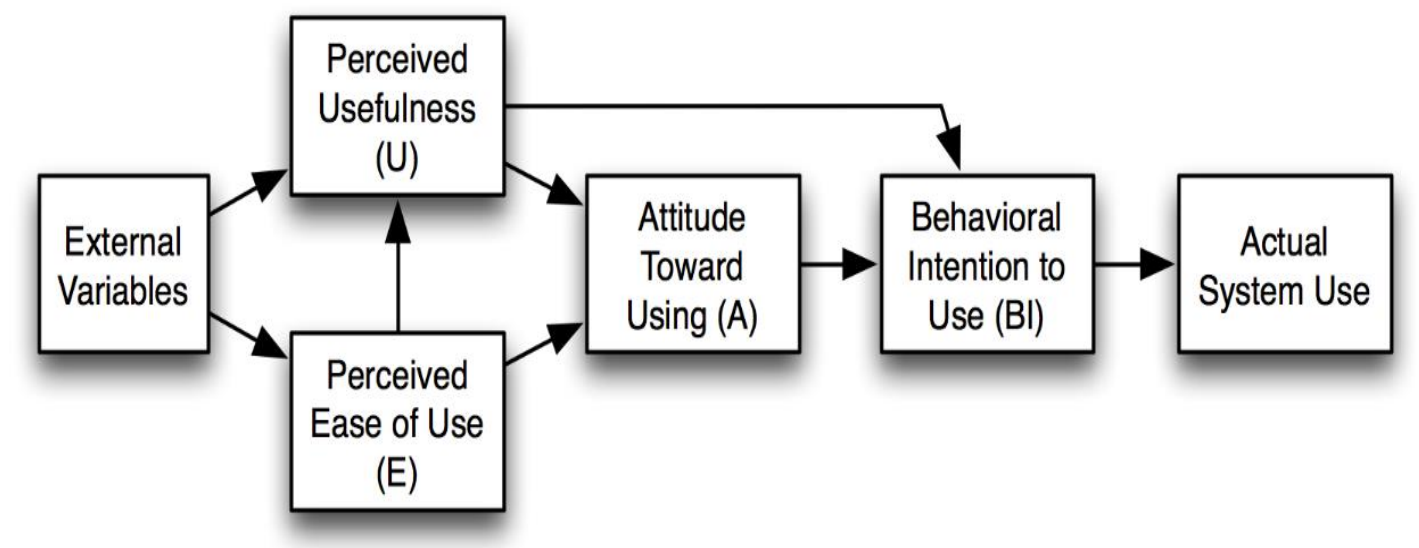

\section{Perceived Usefulness (PU)}

First expectation of people while using new technology is to find if the new application is useful? Is the new technology useful? This is the question that people will raise in their mind before fully accepting the technology. If the new technology is not useful these people will not accept the technology. "People tend to use or not use an application to the extent they believe it will help them perform their job better. The degree to which a person believes that using a particular system would enhance his or her job performance" (Davis, 1989).

\section{Perceived Ease of Use (PEOU)}

When people are given technology to use, there first expectation will be whether the use of technology brings simplicity to what they are doing with in the past. The way of using the new technology should be easy. People expect to learn the new technology very fast. The easier the technology is the faster people are expected to accept the technology. "The degree to which an individual believes that using a particular information technology system would be free of effort. An application perceived to be easier to use than another is more likely to be accepted by users" (Davis, 1989).

\section{Attitude towards Using}

The two variables explained above shapes an attitude towards the technology. Eagly and Chaiken (1998) suggests that "an attitude is a psychological tendency that is expressed by evaluating a particular entity with some degree of favor or disfavor" PE and PEOU develops a favor or disfavor among technology users. This phenomenon is also known as attitude towards using of the technology. 


\section{Behavioral Intention to Use (BI)}

Behavior Intention is the degree to which a person has formulated conscious plans to perform or not perform some specified future behavior. (Warsha \& Davis, 1985) Behavior intention to use means the conscious action performed by a person to use technology. Whenever a new technology is presented to a person there are factors that shape their behavior to use or not to use the technology. In TAM 1989, Davis explains that PEOU and PU are responsible to shape the behavior intention.

So, TAM basically explains about how two major construct PEOU and PU are responsible in shaping behavioral intention and finally the intention is reflected in actual usage of the technology.

\section{Theoretical Framework}

For this research following framework has been adopted after analyzing the evolutions of Technological Acceptance Model.

\section{Figure 2}

\section{Theoretical Framework}

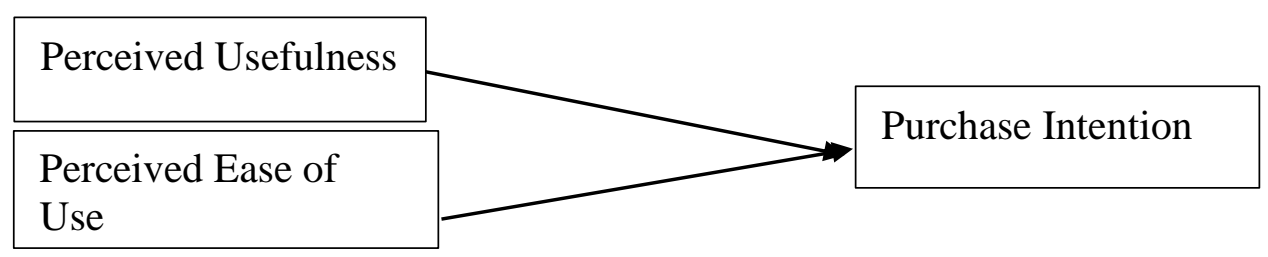

\section{Research Limitation}

However, this study has a few limitations. First, since the survey was conducted within the geographical area of Province No.1, capital city Biratnagar, the results should be interpreted carefully, in context to generalization of Facebook users as a whole. Second, the sample population $(n=275)$ represents fraction of the Facebook user in Biratnagar. Future researcher should focus on larger sample of Facebook users. Future researchers can use other social media sites for the study like Twitter, YouTube etc. In spite of these limitation, this study can be a base for future researchers, practitioners and educators by extending the current model in developing countries.

\section{Methods and Materials}

This research was conducted in Biratnagar Metropolitan City. Biratnagar is the Capital city of Province No.1 of Nepal. The study is focused at determining the purchase intention influenced by Facebook applying TAM. The Simple Random Sampling Method was employed to select sample respondents. This method gives equal chance of getting selected. 275 is the sample size. 
Both quantitative and qualitative data were used. Qualitative data was obtained from primary source whereas both primary and secondary source for quantitative data. Questionnaire was used to collect the primary data and journals, manuals, internet, books for secondary data. The instrument for data collection was questionnaire. To meet the specified objectives, both descriptive and inferential statistics methods were employed. Descriptive statistics and inferential statistics like correlation and multiple regressions were used to derive meaningful information. The data entry and analysis were performed by using Microsoft Excel and Statistical Package for Social Science (SPSS) version 26.0. The data are 76.7\% reliable.

\section{Results and Discussion}

The interpretation and presentation of the data that is collected during the study through the questionnaire are analyzed and presented in this chapter. The outcomes derived from the analysis of the data are expected to address the objective of this research study. The analysis has been framed in single sections that deals with demographic features of the respondent's, interpretation of descriptive analysis using SPSS, correlation of dependent and independent variables and finally the discussion of the results obtained through the analysis.

\section{Demographic Analysis}

This section includes the demographic characteristics of the respondents, its analysis and interpretation of the data collected through questionnaires. The demographic characteristic under this study comprises age, gender, income, marital status, educational qualification, occupation and use, usage and frequency of Facebook of the respondents.

\section{Table 1}

Demographic Characteristics of Respondents

\begin{tabular}{llll}
\hline \multicolumn{1}{c}{ Description } & & Frequency & Percentage \\
\hline Age & $15-15$ & 76 & 27.6 \\
& $26-35$ & 156 & 56.7 \\
\multirow{3}{*}{ Gender } & 35 and above & 43 & 15.6 \\
& Male & 205 & 74.5 \\
Marital Status & Female & 70 & 25.5 \\
& Married & 119 & 43.3 \\
Education Status & Unmarried & 156 & 56.7 \\
& Upto Intermediate & 13 & 4.7 \\
& Bachelors & 98 & 35.6 \\
& Masters and above & 164 & 59.6
\end{tabular}




\begin{tabular}{|c|c|c|c|}
\hline \multicolumn{2}{|l|}{ Description } & \multirow{2}{*}{$\begin{array}{l}\text { Frequency } \\
167\end{array}$} & \multirow{2}{*}{$\frac{\text { Percentage }}{60.7}$} \\
\hline Occupation & Employed & & \\
\hline & Unemployed & 10 & 3.6 \\
\hline & Self-Employed & 49 & 17.8 \\
\hline & Student & 49 & 17.8 \\
\hline \multirow[t]{5}{*}{ Income } & Less than 15,000 & 54 & 19.6 \\
\hline & 15,001 to 30,000 & 52 & 18.9 \\
\hline & 30,001 to 45,000 & 43 & 15.6 \\
\hline & 45,001 to 60,000 & 61 & 22.2 \\
\hline & 60,001 and above & 65 & 23.6 \\
\hline \multirow[t]{5}{*}{ How long do you use Facebook? } & Less than an Hour & 74 & 26.9 \\
\hline & 2 hours & 88 & 32.0 \\
\hline & 3 hours & 38 & 13.8 \\
\hline & 4 hours & 22 & 8.0 \\
\hline & 4 hours and above & 53 & 19.3 \\
\hline \multirow{3}{*}{$\begin{array}{l}\text { What is your Facebook use } \\
\text { frequency? }\end{array}$} & Daily & 259 & 94.2 \\
\hline & 2-4 times a week & 11 & 4.0 \\
\hline & Once a week & 5 & 1.8 \\
\hline \multirow[t]{5}{*}{$\begin{array}{l}\text { Why do you use Facebook most } \\
\text { for? }\end{array}$} & $\begin{array}{l}\text { To keep contact with family } \\
\text { and friends }\end{array}$ & 154 & 56.0 \\
\hline & For entertainment & 57 & 20.7 \\
\hline & To get news & 45 & 16.4 \\
\hline & To follow brands/companies & 5 & 1.8 \\
\hline & $\begin{array}{l}\text { To strengthen professional } \\
\text { network }\end{array}$ & 14 & 5.1 \\
\hline
\end{tabular}

Note. Survey questionnaire.

A total of 275 respondent from Biratnagar participated in this study. Major respondent was Male (74.5\%), between the age range of 26-35 years (56.7\%), unmarried (56.7\%) studying Masters and above (59.6\%) earning Rs. 60,001 and above and employed (60.7\%). 
Majority of respondent used Facebook for 2 hours (32\%) and their usage frequency was daily $(94.2 \%)$. The basic reason behind the use of Facebook was for contacting family and friends $(56 \%)$ as people are influenced by Word of Mouth and opinion given from the people, they know in Facebook affecting the buying behavior but don't care about the Brand image (R. Arunima. 2019). The data are presented in the Table 1.

\section{Reliability and Validity of Scales}

To test the reliability, Cronbach Alpha coefficient was used. To check the reliability of scales coefficient must be above 0.70 . The general alpha coefficients are found as perceived usefulness (0.842) and perceived ease to use (0.732). According to this result, it is possible to say that research has a good degree of reliability.

\section{Table 2}

Reliability and Validity of Scales

\begin{tabular}{rc}
\hline Constructs & Cronbach's Alpha \\
\hline Perceived Usefulness & 0.842 \\
Perceived Ease of use & 0.732
\end{tabular}

Note. Survey questionnaire

\section{Pearson Correlation Results of the Variables}

Table 3 shows the correlation between two factors i.e. perceived usefulness and perceived ease to use and purchase intention. Accordingly, both the factors have a positive and significant relationship with purchase intention. However, the degree of correlation of perceived usefulness is .371 and perceived ease of use is .352 .

\section{Table 3}

Pearson Correlation Results of Variables

\begin{tabular}{lll}
\hline \multicolumn{1}{c}{ Variables } & PI \\
\hline PU & Pearson Correlation & $.371^{* *}$ \\
& Sig. (2-tailed) & 0.000 \\
\multirow{3}{*}{ POEU } & N & 275 \\
& Pearson Correlation & $.352^{* *}$ \\
& Sig. (2-tailed) & 0.000 \\
PI & N & 275 \\
& Pearson Correlation & 1 \\
& Sig. (2-tailed) & \\
\hline
\end{tabular}

Note. Survey questionnaire. 


\section{Multiple Regression Analysis}

In this study, there are two independent variables namely perceived usefulness and perceived ease to use that determines the Facebook influence on purchase intention. The table shows no case of multicollinearity as VIF lies between 1 to 5 . To test the influence of these variables on the purchase intention, the study used multiple regression analysis.

The table 4 shows the multiple regression between two independent variables and purchase intention influenced by Facebook in Biratnagar. This indicates that the independent variables (perceived usefulness and perceived ease to use) significantly influence the purchase intention. The regression coefficient of perceived usefulness is 0.210 which indicates one-unit increase in perceived usefulness increases purchase intention by 0.210 and corresponding pvalue is 0.002 which is less than alpha 0.05 indicates significant relationship between perceived usefulness and purchase intention. The regression coefficient of perceived ease to use is 0.178 which indicates one-unit increase in perceived ease to use increases purchase intention by 0.178 and corresponding p-value is 0.027 which is less than alpha 0.05 indicates significant relationship between perceived ease to use and purchase intention.

Moreover, R-square is $52.3 \%$ which states that the independent variables explain dependent variables by $52.3 \%$.

\section{Table 4}

Multiple Regression Analysis

\begin{tabular}{|c|c|c|c|c|c|}
\hline \multirow{2}{*}{ Model } & \multicolumn{2}{|c|}{$\begin{array}{c}\text { Unstandardized } \\
\text { Coefficients }\end{array}$} & \multirow{2}{*}{$\begin{array}{c}\text { Standardized } \\
\text { Coefficients }\end{array}$} & \multirow{2}{*}{$\mathrm{t}$} & \multirow{2}{*}{ Sig. } \\
\hline & B & Std. Error & & & \\
\hline (Constant) & & & & 8.133 & 0.000 \\
\hline PU & & & 0.244 & 3.056 & 0.002 \\
\hline POEU & & & 0.177 & 2.222 & 0.027 \\
\hline
\end{tabular}

Dependent Variable: Purchase Intention.

R Square: .523 


\section{Hypothesis}

\section{Table 5}

Summary of Hypothesis

\begin{tabular}{lrrr}
\hline \multicolumn{1}{c}{ Hypothesis } & p value & Remarks \\
\hline $\begin{array}{l}\mathrm{H}_{1} \text { : There is no significant relationship between perceived usefulness and } \\
\text { purchase intention. }\end{array}$ & 0.000 & Rejected \\
$\begin{array}{l}\mathrm{H}_{2} \text { : There is no significant relationship between perceived } \\
\text { ease of use and purchase intention. }\end{array}$ & 0.000 & Rejected \\
\hline
\end{tabular}

\section{Findings}

The study found that perceived usefulness and perceived ease to use have significant relationship between purchase intention. This study reveals that the vital factor that influence purchase intention is perceived usefulness (Koufaris, 2002; Dash \& Saji, 2006). The respondent believed that updated information about the products/services were easily available in Facebook. Facebook even reminded them with new arrivals and modification on old ones. Respondents found it easy to track information on Facebook. Perceived ease to use has significant role in determining purchase intention (Oentario, Y, Agung H and Irawati, J. (2017). Respondent found it easier than other social media to operate Facebook and use it as engine to search for brand information. Finally, the research states that perceived usefulness and perceived ease to use have significant influence on purchase intention.

\section{Conclusions}

This research paper takes the support of Technology Acceptance Model and Trust to determine the influence of Facebook on purchase decision. Among the factors, perceived usefulness and trust positively influenced purchase intention whereas perceived ease to use showed negative influence on purchase intention. It indicates that perceived usefulness and trust are the predictors of purchase intention. Trust was found to be the strongest predictor to influence purchase intention followed by perceived usefulness.

\section{Implications}

Marketing managers should formulate requisite strategies and procedure to create a brand image in the mind of the customers. Messages and ads designed should be as such which it can easily position the intended information. Marketers must focus on the influence of family, friends and relatives because they have influence on the buying behavior. Information about products and services should be easily available while searching for it and should be as required. 


\section{References}

Bakar, A., \& Syuhaidi, M. (2013). Technology acceptance and purchase intention towards movie mobile advertising among youth in Malaysia. Procedia - Social and Behavioral Sciences, 130. https://doi.org/10.1016/j.sbspro.2014.04.065.

Branckaute, F. (2010). Facebook statistics: The numbers game continues. The Blog Herald. http://www.blogherald.com/2010/08/11/facebook-statistics-the-numbers-gamecontinues/

Bruhn, M., Schoenmueller, V., \& Schafer, D. B. (2012). Are social media replacing traditional media in terms of brand equity creation? Management Research Review, 35(9), 770790.

Dash, S. B., \& Saji, K. B. (2006). Role of effective Website Design in online shopping: A large scale empirical study in the Indian Context. Marketing in the New Global Order, Challenges and Opportunities, Excel Books, 435451.

Davis, F. D. (1989). Perceived usefulness, perceived ease of use, and user acceptance of information technology. MIS Quarterly, 13(3), 319-340.

Davis, F. D., Bagozzi, R., \& Warshaw, P. (1989). User acceptance of computer technology: a comparison of two theoretical models. Management Science, 35 (8), 982-1003.

Dehghani, M., \& Tumer, M. (2015). A research on effectiveness of Facebook advertising on enhancing purchase intention of consumers. Computers in Human Behavior, 49, 597600. https://doi.org/10.1016/j.chb.2015.03.051.

Eagly, A. H., \& Chaiken, S. (1998). Attitude structure and function. The handbook of social psychology, 269-322.

Gefen, D., Karahanna, E., \& Straub, D. (2003). Trust and TAM in online shopping: An integrated model. MIS Quarterly. 27. 51-90. https://doi.org/10.2307/30036519.

Isra A. D., Elham A. M., \& Sara, I. (2015). The Impact of social media on consumer buying behavior. Special Topics in Information Systems, 1-12.

Kahraman, M. (2010). How Facebook advertising affects buying behavior of young consumers: The moderating role of gender. Media cat, 2-22.

Kang, K. Y., \& Jin, H. J. (2007). A study on consumers' clothing buying intention adopted by the technology acceptance model. Journal of the Korean Society of Clothing and Textiles, 31. https://doi.org/10.5850/JKSCT.2007.31.8.1211.

Koufaris, M. (2002). Applying the technology acceptance model and flow theory to online consumer behavior. Information Systems Research, 13 (2), 205223. https://doi.org/10.1287/isre.13.2.205.83 
Kountouridou, M., \& Ioannou, P. (2019). Facebook impact on consumer intention-to-buy. Quality Assurance in Higher Education, 3, 1-23.

Lin, X., Li, Y., \& Wang, X. (2017). Social commerce research: Definition, research themes and trends. International Journal of Information Management, 37, 190-201

MacMillan, D. (2009). Facebook banks on a little help from its friends. Bloomberg Businessweek. Retrieved from Businessweek.com website: http://www.businessweek.com/magazine/content/09_43/b4152048040939.htm

Marangrunic, N., \& Granic, A. (2013). Technology acceptance model: a literature review from 1986 to 2013. Universal Access in the Information Society International Journal.

Oentario, Y, Agung H and Irawati, J. (2017). "Perceived Usefulness, Ease of Use, Risk and Intention to Buy Online Patisserie melalui Consumer Attitude Berbasis Media Social diSurabaya”. Journal Management Pemasaran. Vol. 11, No. 1, pp 26-31.

Rauniar, R., \& Rawski., G., Jei, Y., \& Johnson, B. (2014). Technology acceptance model (TAM) and social media usage: An empirical study on Facebook. Journal of Enterprise Information Management, 27. https://doi.org/10.1108/JEIM-04-2012-0011.

Razorfish Social Influence Marketing Report. (2009). www.scribd.com/doc/17305107/Fluent The-Razorfish-Social-Influence-Marketing-Report (accessed August 15, 2013).

Vahl, A. (2011). Create EPIC Facebook Ads. Publication of Hubsport, 2, 2-33.

Wang, Y., \& Sun, S. (2010). Examining the role of beliefs and attitudes in online advertising a comparison between USA and Romania. The International Marketing Review. 3 (1), $362-375$.

Warsha, R., \& Davis, F. (1985). Disentangling behavioral intention and behavioral expectation. International Journal of Interactive Mobile Technologies, 14, 186. https://doi.org/10.3991/ijim.v14i12.15567. 